\title{
Role of FRAX in the Evaluation of Osteoporosis in Patients with Chronic Obstructive Pulmonary Disease
}

\author{
Kronik Obstrüktif Akciğer Hastalığı Hastalarında Osteoporozu \\ Değerlendirmede FRAX'ın Rolü
}

(1) Onur Yazıcı, (1) Şenay Demir Yazıcı*

Aydın Adnan Menderes University Faculty of Medicine, Department of Chest Diseases, Aydın, Turkey

${ }^{*}$ Atatürk State Hospital, Clinic of Physical Medicine and Rehabilitation, Aydın, Turkey

\section{Abstract}

Objective: The incidence of osteoporosis increased in patients with chronic obstructive pulmonary disease (COPD), and fractures due to osteoporosis are a significant cause of morbidity. Thus, risk assessment and taking necessary precautions are essential in these patients. This study aimed to assess the fracture risk of patients with COPD scanned with dual-energy X-ray absorptiometry (DXA) using the fracture risk assessment tool (FRAX) and to identify their treatment status.

Materials and Methods: Patients who presented to the Physical Therapy Outpatient Clinic of Aydın Atatürk State Hospital and diagnosed with COPD between January 2014 and January 2019 were included in the study. Results of DXA and pulmonary function test performed within the last year were recorded. According to the DXA results, patients were divided into osteoporotic, osteopaenic and normal groups. Patients were also classified into group A, B, C and D according to the Global Initiative for Chronic Obstructive Lung Disease classification. FRAX values were calculated using an online calculator.

Results: Ninety-five patients with COPD were enrolled in the study. According to their DXA values, 39 (41.1\%), 41 (43.2\%) and 15 $(15.8 \%)$ patients were allocated in the osteoporotic, osteopaenic and normal groups, respectively. The 10-year major osteoporotic and hip fracture risks, calculated using FRAX, was the highest in the osteoporotic group, followed by the osteopaenic group ( $p<0.001$ and $p<0.001$, respectively). Thirty-six patients (92.3\%) in the osteoporotic group received medical treatment for osteoporosis, whereas only 13 (31.7\%) patients in the osteopaenic group received medical treatment. FRAX assessment revealed that both major osteoporotic and hip fracture risks were higher in groups $C$ and $D(p=0.002$ and $p=0.002$, respectively).

Conclusion: All patients with COPD, particularly those in groups $C$ and $D$, should be assessed with both DXA and FRAX, regarding osteoporosis and fracture risks, and preventive measures/treatment should be planned when required.

Keywords: Osteoporosis, COPD, FRAX

\section{$\ddot{O z}$}

Amaç: Kronik obstrüktif akciğer hastalığı (KOAH) hastalarında osteoporoz sıklığı artmıştır ve osteoporoz sonucunda ortaya çıkan kırıklar önemli bir morbidite nedenidir. Bu nedenle bu hastalarda kırık riskinin değerlendirilmesi ve gereken olgularda önlem alınması gereklidir. Bu çalışmada çift enerjili X-ışını absorbsiyometri (DXA) ile taranan KOAH hastalarının kırık risk değerlendirme aracı (FRAX) ile kırık riskini değerlendirmeyi ve bu hastaların tedavi durumlarını belirlemeyi amaçladık.

Gereç ve Yöntem: Ocak 2014- Ocak 2019 tarihleri arasında Aydın Atatürk Devlet Hastanesi Fizik Tedavi Polikliniği'ne başvuran ve KOAH tanısı olan hastalar çalışmaya alındı. Sistemdeki DXA sonuçları ve son bir yıl içerisinde yapıımış olan solunum fonksiyon test sonuçları kaydedildi. Hastalar DXA sonuçlarına göre osteoporotik, osteopenik ve normal olarak 3 gruba ayrıldı. Hastalar ayrıca Kronik Obstrüktif Akciğer Hastalığına Karşı Küresel Girişim sınıflamasına göre A, B, C ve D olarak 4 sınıfa ayrıldı. Hastaların web üzerinden FRAX değerleri hesaplandı.

Bulgular: Çalışmaya $95 \mathrm{KOAH}$ hastası alındı. DXA değerlerine göre sınıflandırıldığında 39’u $(\% 41,1)$ osteoporotik, 41'i $(\% 43,2)$ osteopenik ve $15^{\prime} \mathrm{i}(\% 15,8)$ normal gruptaydı. FRAX ile hesaplanılan 10 yıllık majör osteoporotik ve kalça kırık riski en yüksek osteoporotik grupta daha sonra ise osteopenik grupta bulundu ( $p$ değerleri sırasıyla <0,001 ve <0,001). Osteoporozu olan hastaların 36'sı (\%92,3) osteoporoz için medikal tedavi almışken, osteopenik grupta $13(\% 31,7)$ hasta medikal tedavi almıştı. Osteopenik grupta tedavi almayan 28 hastanın 5’i $(17,8)$ kalça fraktürü açısından yüksek riskli bulundu. FRAX ile yapılan değerlendirmede C ve D grubunda olan hastalarda hem majör osteoporoz riski hem de kalça fraktürü riski daha yüksekti (p değerleri sırasıyla 0,002 ve 0,002).

Address for Correspondence/Yazışma Adresi: Onur Yazıcı MD, Aydın Adnan Menderes University Faculty of Medicine, Department of Chest Diseases, Aydın, Turkey Phone: +90 2562155613 E-mail: dronur yazici@hotmail.com ORCID ID: orcid.org/0000-0002-6272-4632 Received/Geliş Tarihi: 02.11.2020 Accepted/Kabul Tarihi: 16.03.2021

${ }^{\circ}$ Copyright 2021 by the Turkish Osteoporosis Society / Turkish Journal of Osteoporosis published by Galenos Publishing House 


\section{$\ddot{O z}$}

Sonuç: Başta $C$ ve $D$ grubu olmak üzere tüm $\mathrm{KOAH}$ hastaları osteoporoz ve kırık riski açısından hem DXA hem de FRAX ile birlikte değerlendirilerek gereken olgularda koruyucu ve medikal tedavi planlanmalıdır.

Anahtar kelimeler: Osteoporoz, KOAH, FRAX

\section{Introduction}

Chronic obstructive pulmonary disease (COPD) has pulmonary and extrapulmonary effects, has numerous comorbidities, and is characterized by chronic and progressive airway destruction $(1,2)$. Associated comorbidities lead to impairment of the quality of life and increasing duration of hospitalization in COPD patients. One of these comorbidities is osteoporosis, a disorder with a course of reduction in both the mass and microarchitecture of bone, eventually leading to fractures $(3,4)$. Conducted studies have reported an increased incidence of osteoporosis, and that this might be related to the causes such as the drugs used, inactivity, cachexia, malnutrition, and inflammation (5). Assessment with dual-energy X-ray absorptiometry (DXA) is considered the golden standard in diagnosing and treating osteoporosis $(6,7)$. Fractures occurring as a consequence of osteoporosis in COPD patients reduce the quality of life of the patient. The hip fracture disables the patient's mobilization, leading to more reduction of the already low exercise capacity, and kyphosis due to vertebral fractures causes a further reduction of the respiratory reserve (8). When individuals with osteoporotic fractures were considered, it was found that fractures occurred not only in the presence of osteoporosis but also in those with osteopenia (9). Thus, the World Health Organization (WHO) constituted a fracture risk assessment tool (FRAX), a web-based algorithm table, to calculate the fracture risk (10). A 10-year hip and major osteoporotic fracture risks are calculated with $\operatorname{FRAX}(11,12)$. During the calculation process, a country-based datasheet is used. Data such as age, gender, height, body weight, previous fracture history, fracture history of the parents, smoking status, steroid use, presence of rheumatoid arthritis or secondary osteoporosis, alcohol use, and the femoral neck score measured by DXA are recorded, and the 10-year hip fracture and major osteoporotic fracture risks are calculated. The obtained fracture risk results guide selection patients to be careful about and apply preventive measures early. In a patient with not too low DXA measurement, a high fracture risk may be calculated with FRAX. In this case, such patients should be warned regarding preventive measures, an exercise program should be given to prevent falls, and they should be assessed for treatment. In our study, we aimed to evaluate the fracture risk with FRAX in COPD patients screened with DXA and identify these patients' treatment status.

\section{Materials and Methods}

The study was initiated following the approval of the Aydın Adnan Menderes University Ethics Committee for Non-Interventional
Clinical Research (protocol no: 2019/26, date: 07.02.2019). In our study, the data of the patients who presented to the Physical Therapy Outpatient Clinic of Aydın Atatürk State Hospital and diagnosed with COPD between January 2014 and January 2019 were investigated in the digital environment. Information was given to the phone-reached patients who had a pulmonary function test (PFT) result within the last year and whose DXA data for osteoporosis was accessed in the system. Patients who agreed to participate in the study and signed the informed consent form were included. Patients with conditions that can affect DXA measurements, such as extensive degenerative disorders, laminectomy, or prosthesis, were excluded from the study.

\section{Study Protocol}

The patients' demographic characteristics, such as age, gender, and body mass index (BMI), were recorded. BMI was calculated using the formula [BMl=body weight/height $\left.{ }^{2}\left(\mathrm{~kg} / \mathrm{m}^{2}\right)\right]$. The patients were divided into three groups according to their DXA results found in the system as osteoporotic, osteopenic, and normal based on the WHO classification (13). Based on this categorization, patients with an L1-L4 vertebra total T-score or femoral neck T-score or femur total T-score was equal or under -2.5 were considered osteoporotic, those between -1 and -2.5 osteopenic, and those over -1 normal. All three groups were questioned regarding whether they had received medical treatment for osteoporosis. Previous fracture history, fracture history of the parents, smoking status and alcohol use, steroid use, rheumatoid arthritis, or causes of secondary osteoporosis were questioned and recorded. The patient's information and the femoral neck T-score were entered in the internet database, and the FRAX algorithm on the web site provided by WHO for Turkey was applied for each patient (14). The 10-year hip fracture and major osteoporotic fracture risks of the patients were calculated. Using the fracture risk threshold values suggested by the National Osteoporosis Foundation, the patients were divided into high-fracture-risk and low-fracture-risk groups. Patients with a 10-year hip fracture risk of over 3\% were considered high-risk, and those equal to or under 3\% were low-risk. Patients with a major osteoporotic fracture risk above $20 \%$ were considered high-risk, and those equal to or below $20 \%$ as low risk (15). PFTs of the patients performed within the last year were evaluated. Forced vital capacity (FVC) \%, forced expiratory volume $1^{\text {st }}$ second (FEV1) \%, and FEV1/FVC were recorded. Modified Medical Research Council (mMRC) dyspnea scale and COPD assessment test (CAT) were performed in all cases for clinical assessment. mMRC dyspnea scale reveals the activity limitation due to shortness of breath and is graded between 0 
and 4 (16). CAT is a test measuring the health status of COPD patients, and there are eight items related to symptoms, exercise limitation, sleep status, and confidence level of the patient. The patient's answer for each test item is scored between 0 and 5 , and the total score ranges between 0 and 40 (17).

COPD patients in the study were classified into four groups based on the Global Initiative for Chronic Obstructive Lung Disease (GOLD) 2017 criteria. According to this, patients with a high symptom frequency were placed in groups $B$ or $D$, and those with high exacerbation risk in groups $C$ or $D(1)$. Patients were divided into two separate groups as those in groups $A$ and $B$ with less frequent exacerbation and those in groups $C$ and $D$ with more frequent exacerbation.

\section{Statistical Analysis}

The data obtained were analyzed using the SPSS software package (SPSS 23, IBM Corp., released in 2015, IBM SPSS Statistics for Windows, Version 23., Armonk, NY, USA). The Kolmogorov-Smirnov test analyzed the conformity of variables to normal distribution. Regarding the continuous variables, those with a normal distribution were expressed as mean \pm standard deviation and those not in conformity with normal distribution as median (25\%-75\%). Categorical variables were expressed as numbers and percentages. The Student t-test was used to compare two groups regarding continuous variables with a normal distribution and the Mann-Whitney $U$ test for those not showing a normal distribution. For comparison of three or more groups regarding continuous variables with a normal distribution, One-Way Analysis of Variance and Tukey HSD test, one of the multi-comparison tests, were used, and for variables not showing normal distribution, the Kruskal-Wallis test, and the Bonferroni-Dunn test, which is another multi-comparison test, were used. The Pearson chi-square and Fisher Exact tests were used for the evaluation of categorical variables. $P<0.05$ was considered statistically significant.

\section{Results}

Data of a total of 226 COPD were reached regarding the specified dates. One hundred thirty-one patients with no DXA or PFT result within the last year of their follow-up were excluded from the study. A total of COPD 95 patients with an average age of $66.26 \pm 8.51$ years, consisting of $80(84.2 \%)$ males and 15 $(15.8 \%)$ females, were included in the study. While $27(28.4 \%)$ patients were active smokers, 61 (64.2\%) were ex-smokers, and $7(7.4 \%)$ had never smoked. The average smoking amount of the patients was $42.75 \pm 28.33$ pack years. The medical histories of all non-smokers involved biomass exposure. According to the GOLD classification system, 21 (22.1\%) patients were in group A, 31 (32.6\%) in group B, 8 (8.4\%) in group C, and 35 (36.8\%) in group $D$. The mean femoral neck T-score of the patients measured with DXA was $-1.66 \pm 1.25$, the mean femur total T-score was $-1.29 \pm 1.2$, and the mean L1-L4 total T-score was $-1.73 \pm 1.38$. According to the calculated FRAX values, the mean 10 -year major osteoporotic fracture risk was $13.66 \pm 8.97 \%$, and the mean 10-year hip fracture risk was $6 \pm 7.08 \%$. The demographic, functional, and laboratory data of the patients were presented in Table 1.

When the patients were grouped according to the DXA criteria determined by WHO, 39 (41.1\%) patients were osteoporotic, 41 (43.2\%) were osteopenic, and 15 (15.8\%) were normal. All three groups were similar regarding the age, female/male ratio, amount of smoking, and COPD duration $(p=0.199, p=0.253$, $p=0.066$, and $p=0.660$, respectively). The FEV1/FVC value was significantly higher in the normal group than the osteopenic group ( $p=0.032$ ). BMl was highest in the normal group and lowest in the osteoporotic group $(p<0.001)$. The mMRC dyspnea scale and CAT scores, which reveal the clinical status, were similar in all three groups ( $p=0.300$ and $p=0.296$, respectively). The 10-year major osteoporotic fracture and hip fracture risks,

Table 1. The demographic, functional, and laboratory data of the patients with chronic obstructive pulmonary disease

\begin{tabular}{|c|c|}
\hline Characteristics & Patients with COPD 95 \\
\hline Age (years) & $66.46 \pm 8.07$ \\
\hline \multicolumn{2}{|l|}{ Gender, n (\%) } \\
\hline Female & $15(15.8)$ \\
\hline Male & $80(84.2)$ \\
\hline $\mathrm{BMI}\left(\mathrm{kg} / \mathrm{m}^{2}\right)$ & $25.31 \pm 4.59$ \\
\hline \multicolumn{2}{|l|}{ Smoking history, n (\%) } \\
\hline Non-smoker & $7(7.4)$ \\
\hline Ex-smoker & $61(64.2)$ \\
\hline Active smoker & $27(28.4)$ \\
\hline Smoking (packs/year) & $40(20-60)$ \\
\hline Duration of COPD & $8(5-12)$ \\
\hline FVC \% pred & $73.28 \pm 15.93$ \\
\hline FEV1 \% pred & $52.47 \pm 15.94$ \\
\hline FEV1/FVC & $57.25(50.73-63.39)$ \\
\hline mMRC score & $2(1-3)$ \\
\hline CAT score & $16(9-22.5)$ \\
\hline \multicolumn{2}{|l|}{ COPD group, n (\%) } \\
\hline A & $21(22.1)$ \\
\hline B & $31(32.6)$ \\
\hline C & $8(8.4)$ \\
\hline D & $35(36.8)$ \\
\hline Femoral neck T-score & $-1.66 \pm 1.25$ \\
\hline Femur total T-score & $-1.29 \pm 1.2$ \\
\hline L1-L4 total T-score & $-1.73 \pm 1.38$ \\
\hline Major osteoporosis & $11(7.57-16)$ \\
\hline Hip fracture & $3.65(1.47-7.72)$ \\
\hline \multicolumn{2}{|c|}{$\begin{array}{l}\text { BMI: Body mass index, COPD: Chronic obstructive pulmonary disease, FVC: } \\
\text { Forced vital capacity, \% pred: Percent predicted, FEV1: Forced expiratory volume } \\
\text { in one second, mMRC: Modified Medical British Research Council dyspnea } \\
\text { questionnaire, CAT: COPD assessment test }\end{array}$} \\
\hline
\end{tabular}


calculated according to FRAX, were significantly different in all three groups ( $p<0.001$ and $p<0.001$, respectively). Regarding major osteoporotic fractures, the fracture risk was high in 7 (\%) patients in the osteoporotic group and 2 (\%) patients in the osteopenic group. Regarding hip fractures, the fracture risk was high in $27(69.2 \%)$ patients in the osteoporotic group and 14 (34.1\%) patients in the osteopenic group. In all patients with normal DXA results, both fracture risks were low. According to the T-score, 36 (92.3\%) patients with osteoporosis and 13 (31.7\%) patients with osteopenia had received medical treatment for osteoporosis. Five (17.8\%) of 28 patients in the osteopenic group who had not received any treatment were found to be at high risk regarding hip fracture (Table 2).

Regarding the COPD groups, 52 patients were in groups $A$ and $B$, which had fewer exacerbations and hospitalizations, and 43 patients were in groups $C$ and D. The patients in groups $C$ and $D$ were older and had a longer duration of COPD diagnosis ( $p=0.003$ and $p<0.001$, respectively). Both groups were similar regarding the female/male ratio, $\mathrm{BMI}$, and the amount of smoking ( $p=0.905, p=0.903$, and $p=0.163$, respectively). The FVC \%, FEV1 \%, FEV1/FVC values, and the mMRC dyspnea scale and CAT scores were higher in the patients in groups $C$ and $D(p<0.001, p<0.001, p=0.001, p<0.001$, and $p<0.001$, respectively). Evaluation with FRAX revealed that both the major osteoporosis and hip fracture risks were significantly higher in the patients in groups $C$ and $D$ when compared to those in groups $A$ and $B(p=0.002$ and $p=0.002$, respectively). On the other hand, both groups were similar regarding the administered medical treatment according to DXA measurements $(p=0.115)$ (Table 3$)$.

\section{Table 2. Demographic, functional, and laboratory data of the patients grouped according to their DXA results}

\begin{tabular}{|c|c|c|c|c|}
\hline Characteristics & $\begin{array}{l}\text { Normal group } \\
(n=15)\end{array}$ & $\begin{array}{l}\text { Osteopenic group } \\
(n=41)\end{array}$ & $\begin{array}{l}\text { Osteoporotic group } \\
(n=39)\end{array}$ & $p$ \\
\hline Age (years) & $66.6 \pm 7.22$ & $64.85 \pm 7.58$ & $68.1 \pm 7.58$ & 0.199 \\
\hline \multicolumn{5}{|l|}{ Gender, n (\%) } \\
\hline Female & $2(13.3)$ & $4(9.8)$ & $9(23.1)$ & \multirow{2}{*}{0.253} \\
\hline Male & $13(86.7)$ & $37(90.2)$ & $30(76.1)$ & \\
\hline BMI $\left(\mathrm{kg} / \mathrm{m}^{2}\right)$ & $29.42 \pm 4.01$ & $25.66 \pm 4.24$ & $23.37 \pm 4.07$ & $<0.001^{*}$ \\
\hline \multicolumn{5}{|l|}{ Smoking, n (\%) } \\
\hline Non-smoker & $1(6.7)$ & $2(4.9)$ & $4(10.3)$ & \multirow{3}{*}{0.896} \\
\hline Ex-smoker & $10(66.7)$ & $26(63.4)$ & $25(64.1)$ & \\
\hline Active smoker & $4(26.6)$ & $13(31.7)$ & $10(25.6)$ & \\
\hline Smoking (packs/year) & $50(40-75)$ & $40(30-55)$ & $30(20-50)$ & 0.066 \\
\hline COPD duration & $8(6-10)$ & $7(5-10)$ & $10(5-15)$ & 0.660 \\
\hline FVC (\% pred) & $76.38 \pm 12.93$ & $76.07 \pm 14.67$ & $69.24 \pm 17.6$ & 0.116 \\
\hline FEV1 (\% pred) & $58.88 \pm 12.02$ & $54.02 \pm 15.92$ & $48.41 \pm 16.49$ & 0.067 \\
\hline FEV1/FVC & $62.77(58.04-64.84)$ & $56.46(48.06-62.97)$ & $57.2(51.38-62.3)$ & $0.082^{\gamma}$ \\
\hline mMRC score & $2(1-3)$ & $2(1-3)$ & $2(2-3)$ & 0.300 \\
\hline CAT score & $12(6-20)$ & $14(8.5-21.5)$ & $19(12-23)$ & 0.296 \\
\hline Major osteoporosis risk & $2.7(2.2-3.2)$ & $4.7(3.5-7.8)$ & $11(6.3-18)$ & $<0.001^{\star}$ \\
\hline \multicolumn{5}{|c|}{ Major osteoporosis risk, n (\%) } \\
\hline Low & $15(100)$ & $39(95.1)$ & $32(82.1)$ & \multirow{2}{*}{$0.033^{\tau}$} \\
\hline High & $0(0)$ & $2(4.9)$ & $7(17.9)$ & \\
\hline Hip fracture risk & $0.4(0.2-0.7)$ & $1.8(0.85-3.8)$ & $5(2.4-11)$ & $<0.001^{*}$ \\
\hline \multicolumn{5}{|l|}{ Hip fracture risk, $n(\%)$} \\
\hline Low & $15(100)$ & $27(65.9)$ & $12(30.8)$ & \multirow{2}{*}{$<0.001^{*}$} \\
\hline High & $0(0)$ & $14(34.1)$ & $27(69.2)$ & \\
\hline \multicolumn{5}{|l|}{ Treatment status, n (\%) } \\
\hline Non-treated & $15(100)$ & $28(68.3)$ & $3(7.7)$ & \multirow{2}{*}{$<0.001^{*}$} \\
\hline Treated & $0(0)$ & $13(31.7)$ & $36(92.3)$ & \\
\hline
\end{tabular}




\section{Discussion}

Hip and vertebral fractures occurring due to osteoporosis cause both impairments of patients' quality of life and significantly burden the country's economy. Thus, identifying the patient groups at risk, and in addition to preventive measures, administering medical treatment to such patients when required might reduce the occurrence of fractures.

Besides osteoporosis, the incidence of balance disorder and falls are also increased in COPD patients $(18,19)$. For this reason, the COPD patient group is a group that should immensely be paid attention to during screening for osteoporosis. Because fractures due to osteoporosis prevent mobilization and reduce the pulmonary reserve even further, the quality of life is impaired in COPD patients (3). Among these patients, with an evaluation made by DXA only, some at risk of fracture might escape the attention. When patients with a fracture history were analyzed, osteoporotic fractures were more frequent in the osteoporotic group and the osteopenic group (20). In our study also, a high 10-year hip fracture risk was determined in 14 (34.2\%) patients in the osteopenic group, but five (35.7\%) of these patients had not received any treatment.

When fracture risk evaluation was performed according to the subgroups of COPD, significantly higher FRAX values were determined in groups $C$ and $D$ than groups $A$ and $B$.

\section{Table 3. Demographic, functional, and laboratory data of the patients grouped according to their COPD groups}

\begin{tabular}{|c|c|c|c|}
\hline & $\begin{array}{l}\text { COPD groups A+B } \\
(n=52)\end{array}$ & $\begin{array}{l}\text { COPD groups C+D } \\
(n=43)\end{array}$ & p \\
\hline Age (years) & $64.25 \pm 8.06$ & $69.13 \pm 7.32$ & 0.003 \\
\hline \multicolumn{4}{|l|}{ Gender, n (\%) } \\
\hline Female & $8(15.4)$ & $7(16.3)$ & \multirow{2}{*}{0.905} \\
\hline Male & $44(84.6)$ & $36.8(83.7)$ & \\
\hline BMI $\left(\mathrm{kg} / \mathrm{m}^{2}\right)$ & $25.36 \pm 3.91$ & $25.26 \pm 5.34$ & 0.913 \\
\hline \multicolumn{4}{|l|}{ Smoking status, n (\%) } \\
\hline Non-smoker & $5(9.6)$ & $2(4.7)$ & \multirow{3}{*}{0.631} \\
\hline Ex-smoker & $33(63.5)$ & $28(65.1)$ & \\
\hline Active smoker & 14 (26.9) & $13(30.2)$ & \\
\hline Smoking (pack year) & $37.5(20-50)$ & $40(25-60)$ & 0.163 \\
\hline COPD duration (years) & $6(5-8)$ & $10(7-15)$ & $<0.001$ \\
\hline FVC (\% pred) & $80.52 \pm 14.81$ & $64.7 \pm 12.72$ & $<0.001$ \\
\hline FEV1 (\% pred) & $58.92 \pm 14.5$ & $44.81 \pm 14.19$ & $<0.001$ \\
\hline FEV1/FVC & $59.86(55.03-64.84)$ & $54.43(47.2-60.3)$ & 0.001 \\
\hline mMRC score & $1.5(1-2)$ & $3(2-3)$ & $<0.001$ \\
\hline CAT score & $10(8-17.5)$ & $20(16-24)$ & $<0.001$ \\
\hline Femoral neck T-score & $-1.37 \pm 1.09$ & $-2.02 \pm 1.34$ & 0.011 \\
\hline Femur total T-score & $-1.01 \pm 1.08$ & $-1.63 \pm 1.26$ & 0.012 \\
\hline L1-L4 total T-score & $-1.51 \pm 1.29$ & $-2.01 \pm 1.45$ & 0.073 \\
\hline Major osteoporosis & $4.7(3.4-8.25)$ & $8.8(4.9-17)$ & 0.002 \\
\hline \multicolumn{4}{|c|}{ Major osteoporosis risk, $\mathrm{n}(\%)$} \\
\hline Low & $50(96.2)$ & $36(83.7)$ & \multirow{2}{*}{0.043} \\
\hline High & $2(3.8)$ & $7(16.3)$ & \\
\hline Hip fracture & $1.65(0.55-3.8)$ & $3.9(1.7-10)$ & 0.002 \\
\hline \multicolumn{4}{|l|}{ Hip fracture risk, $n(\%)$} \\
\hline Low & $38(73.1)$ & $16(37.2)$ & \multirow{2}{*}{$<0.001$} \\
\hline High & $14(26.9)$ & $27(62.8)$ & \\
\hline \multicolumn{4}{|c|}{ Treatment status, $\mathrm{n}(\%)$} \\
\hline Non-treated & $29(55.8)$ & $17(39.5)$ & \multirow{2}{*}{0.115} \\
\hline Treated & $23(44.2)$ & $26(60.5)$ & \\
\hline
\end{tabular}


Besides, all of the osteopenic patients with a high hip fracture risk according to FRAX but who had not received any treatment were in group D. We think that because COPD patients in the $C$ and $D$ groups are patients who encounter more frequent exacerbations, hospitalizations, and receive steroid treatment more frequently (1), fracture risk is higher in these groups. We also think that COPD patients who are identified as osteopenic when evaluated with DXA only, particularly those in groups $C$ and $D$, should be evaluated more carefully and that early-onset treatment can prevent fractures that might occur in the future. As a result of our study, we think that FRAX has various weaknesses in evaluating COPD patients. First of all, during the FRAX calculation, current smoking status is marked as "no" if the patient is not an active smoker. However, most of the COPD patients who quit smoking have a long duration of smoking in their lives. It is well known that smoking increases fracture risk. With the increasing amount and duration of smoking, the risk of fracture also increases $(21,22)$.

On the other hand, there are not enough studies on how the risk of fracture changes following smoking cessation. A study reported that at least ten years must have passed after smoking cessation for smoking to be ineffective regarding fracture risk (23). In our study, $64.2 \%$ of the patients were ex-smokers, and most of them had quit smoking recently. The mean cigarette use of the patients was as high as $42.75 \pm 28.33$ packs/year. We think that questioning previous smoking status and its amount besides the current smoking status during FRAX calculation will reflect fracture risk more accurately.

Secondly, during FRAX calculation, current steroid use is questioned, and if the patient is not using systemic steroids at that period, that section is marked as "no". As a result, the osteoporosis risk is calculated as low. Most COPD patients, particularly those in groups $C$ and $D$, use inhaled steroids known to increase osteoporosis risk (3). On the other hand, patients in these groups use systemic steroids from time to time due to their frequent exacerbations or hospitalizations. We think that evaluating after adding inhaled steroids to the datasheet will be more accurate in FRAX calculation.

According to the recommendations of $\mathrm{WHO}$, while treatment is indicated in normal patients who have a lumbar vertebra total T-score, femoral neck score, or femur total T-score equal to or over -2.5, in COPD patients, it is indicated in the osteopenic group with a score equal to or over-1 (24). However, in our study, $28(68.3 \%)$ patients in the osteopenic group had not received any treatment, suggesting that treatment might have been neglected while evaluating the osteopenic group among COPD patients. According to DXA, when we evaluated the fracture risk of untreated patients in the osteopenic group, we determined that the hip fracture risk was high in $17.8 \%$ of the group. We think that this ratio will increase when the deficiencies of FRAX are corrected. Despite shortcomings of FRAX evaluation, if both DXA and FRAX are used together, the physician's awareness would increase, leading to requestion the necessity of treatment in particularly the osteopenic group.
The number of studies related to FRAX in determining the fracture risk has increased in recent years $(9,25-28)$. However, enough data regarding which disorders FRAX should be used in or which treatment should be preferred and its combined use with DXA during follow-up has not accumulated yet (29). As such studies increase in number, the necessity of use, priority, or deficiencies of FRAX will be manifest more clearly.

\section{Study Limitations}

There are some limitations in our study. Firstly, the number of female patients in our study was small because of the higher rate of patients with COPD in men. Secondly, the number of patients was small in the COPD subgroups.

\section{Conclusion}

In the calculation of FRAX, the parts on the current smoking status and steroid use should be rearranged. All COPD patients, particularly those in groups $C$ and $D$, should be assessed with both DXA and FRAX regarding the risks of osteoporosis and fracture, and then preventive and medical treatment should be planned when required.

\section{Ethics}

Ethics Committee Approval: The study was initiated following the approval of the Aydın Adnan Menderes University Ethics Committee for Non-Interventional Clinical Research (protocol no: 2019/26, date: 07.02.2019).

Informed Consent: Patients who agreed to participate in the study and signed the informed consent form were included.

Peer-review: Externally and internally peer-reviewed.

\section{Authorship Contributions}

Surgical and Medical Practices: O.Y., Ş.D.Y., Concept: O.Y., Ş.D.Y., Design: O.Y., Ş.D.Y., Data Collection or Processing: O.Y., Ş.D.Y., Analysis or Interpretation: O.Y., Ş.D.Y., Literature Search: O.Y., Ş.D.Y., Writing: O.Y., Ş.D.Y.

Conflict of Interest: No conflict of interest was declared by the authors.

Financial Disclosure: The authors declared that this study received no financial support.

\section{References}

1. Global Strategy for the Diagnosis, Management and Prevention of COPD, Global Initiative for Chronic Obstructive Lung Disease (GOLD) 2017. Available from: http://goldcopd.org

2. Okutan $\mathrm{O}$, Ayten Ö. Kronik Obstrüktif Akciğer Hastalığı ve Komorbiditeler. Solunum 2012;14:181-3.

3. Inoue D, Watanabe R, Okazaki R. COPD and osteoporosis: links, risks, and treatment challenges. Int J Chron Obstruct Pulmon Dis 2016;11:637-48.

4. Sindel D, Gula G. Assessment of Bone Mineral Density in Osteoporosis. Turk J Osteoporos 2015;21:23-9.

5. Chaplynska N, Rudnyk V. Secondary Osteoporosis in Patients with Chronic Obstructive Pulmonary Disease. Galician Med J 2019;26:201916.

6. Akpolat V. Bone Mineral Density Measurement Methods That Are Used At Diagnosis of Osteoporosis. Dicle Med J 2008;35:216-20. 
7. Erdem HR. Diagnostic Methods in Osteoporosis. Turkiye Klinikleri J PM\&R-Special Topics 2012;5(Suppl 3):6-10.

8. Ogura-Tomomatsu H, Asano K, Tomomatsu K, Miyata J, Ohmori $\mathrm{N}$, Kodama $\mathrm{M}$, et al. Predictors of osteoporosis and vertebral fractures in patients presenting with moderate-to-severe chronic obstructive lung disease. COPD 2012;9:332-7.

9. Aslan A, Konya MN, Yağcl \$̧, Karakoyun Ö. Is Turkish FRAX® Model Sufficient? The Analysis of Osteoporotic Fracture Risk in Turkish Population by Using Frax. Turk J Osteoporos 2014;20:21-5.

10. Levasseur R, Sabatier JP, Guilcher C, Guaydier-Souquières G, Costentin-Pignol $V$, Jean-Jacques PY, et al. Medical management of patients over 50 years admitted to orthopedic surgery for lowenergy fracture. Joint Bone Spine 2007;74:160-5.

11. Ipek A, Gafuroğlu Ü, Bodur H, Yılmaz Ö. Osteoporosis risk assessment. Turk J Phys Med Rehap 2012;58:212-9.

12. Tuzun S, Eskiyurt N, Akarirmak U, Saridogan M, Senocak $M$, Johansson $\mathrm{H}$, et al. Incidence of hip fracture and prevalence of osteoporosis in Turkey: the FRACTURK study. Osteoporos Int 2012;23:949-55.

13. Blake GM, Fogelman I. The role of DXA bone density scans in the diagnosis and treatment of osteoporosis. Postgrad Med J 2007:83:509-17.

14. FRAX WHO Fracture Risk Assessment Tool. Available from:s URL: https://www.sheffield.ac.uk/FRAX/tool.aspx? country=6 Accessed June 20, 2020.

15. National Osteoporosis Foundation (NOF). Clinician's guide to prevention and treatment of osteoporosis. Available from: www. nof.org; 2014 Accessed June 15, 2020.

16. Bestall JC, Paul EA, Garrod R, Garnham R, Jones PW, Wedzicha JA. Usefulness of the Medical Research Council (MRC) dyspnoea scale as a measure of disability in patients with chronic obstructive pulmonary disease. Thorax 1999;54:581-6.

17. Jones PW, Harding G, Berry P, Wiklund I, Chen WH, Kline Leidy N. Development and first validation of the COPD Assessment Test. Eur Respir J 2009;34:648-54.

18. Beauchamp MK, Sibley KM, Lakhani B, Romano J, Mathur S, Goldstein RS, et al. Impairments in systems underlying control of balance in COPD. Chest 2012;141:1496-503.
19. Roig M, Eng JJ, Macintyre DL, Road JD, Reid WD. Postural Control Is Impaired in People with COPD: An Observational Study. Physiother Can 2011;63:423-31.

20. Gül O, Atik OŞ, Erdoğan D, Göktaş G. Is bone microstructure different between osteopenic and osteoporotic patients with femoral neck fracture. JT Dis Relat Surg 2012;23:15-9.

21. Wong PK, Christie JJ, Wark JD. The effects of smoking on bone health. Clin Sci (Lond) 2007;113:233-41.

22. Ward KD, Klesges RC. A meta-analysis of the effects of cigarette smoking on bone mineral density. Calcif Tissue Int 2001;68:25970.

23. Cornuz J, Feskanich D, Willett WC, Colditz GA. Smoking, smoking cessation, and risk of hip fracture in women. Am J Med 1999;106:311-4.

24. Sosyal Güvenlik Kurumu Sağlık Uygulama Tebliği. Available from: http://www.sgk.gov.tr/

25. Cauley JA, El-Haij Fuleihan G, Luckey MM; FRAX( ( $)$ Position Development Conference Members. FRAX ${ }^{\circledR}$ International Task Force of the 2010 Joint International Society for Clinical Densitometry \& International Osteoporosis Foundation Position Development Conference. J Clin Densitom 2011;14:237-9.

26. Korthoewer D, Chandran M; Endocrine and Metabolic Society of Singapore. Osteoporosis management and the utilization of FRAX ${ }^{\circ}$ : a survey amongst health care professionals of the AsiaPacific. Arch Osteoporos 2012;7:193-200.

27. Nakatoh S, Takemaru Y. Application of the fracture risk assessment tool $(F R A X(\circledast))$ and determination of suitable cut-off values during primary screening in specific health check-ups in Japan. J Bone Miner Metab 2013;31:674-80.

28. Anar C, Yüksel Yavuz M, Güldaval F, Varol Y, Kalenci D. Assessment of osteoporosis using the FRAX method and the importance of vitamin D levels in COPD patients. Multidiscip Respir Med 2018;13:1.

29. Gültekin SS, Arslan MS, Topaloğlu O, Delibasi. Fracture Risk Analysis in Postmenopausal Women with the Current Methods. J Clin Anal Med 2015;6:541-4. 